\title{
Soil Nitrous oxide and Carbon dioxide emissions following incorporation of above- and below-ground biomass of green bean
}

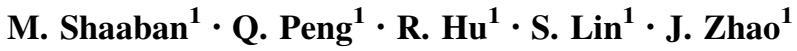

Received: 18 March 2014/Revised: 17 April 2015/Accepted: 4 July 2015/Published online: 22 July 2015

(C) Islamic Azad University (IAU) 2015

\begin{abstract}
Information on soil $\mathrm{N}_{2} \mathrm{O}$ and $\mathrm{CO}_{2}$ emissions from above- and below-ground biomass of legume crops is limited in scientific literature. Therefore, a laboratory study was conducted to evaluate the differences in soil $\mathrm{N}_{2} \mathrm{O}$ and $\mathrm{CO}_{2}$ emissions from the above- and below-ground biomass of green bean. Leave and shoot (LS) and root nodule (Nod) of green bean were incorporated into soil and incubated for 53 days. $\mathrm{N}_{2} \mathrm{O}$ and $\mathrm{CO}_{2}$ emissions were measured throughout the 53-day study period. Incorporation of organic residues significantly $(p \leq 0.05)$ increased $\mathrm{N}_{2} \mathrm{O}$ and $\mathrm{CO}_{2}$ emissions. However, the Nod treatment yielded higher emissions of $\mathrm{N}_{2} \mathrm{O}$ as compared to LS treatment. Cumulative $\mathrm{N}_{2} \mathrm{O}$ emissions were 13 -fold and fourfold in Nod and LS treatment as compared to the control, respectively. $\mathrm{CO}_{2}$ emissions were higher in LS treatment than that of Nod treatment. Cumulative $\mathrm{CO}_{2}$ emissions were 2.15-fold and 1.15-fold in LS and Nod treatments as compared to the control, respectively. The results of current study suggest that below-ground biomass of legume crops produces higher $\mathrm{N}_{2} \mathrm{O}$ emissions while $\mathrm{CO}_{2}$ emissions were higher in above-ground biomass.
\end{abstract}

Keywords Carbon dioxide - Crop straw - Dissolved organic carbon $\cdot$ Nitrous oxide $\cdot$ Organic matter $\cdot$ Root residue

\section{R. Hu}

rghu@mail.hzau.edu.cn

1 College of Resources and Environment, Huazhong Agricultural University, Room \#509, Wuhan 430070, Hubei, People's Republic China

\section{Introduction}

Incorporation of crop residues into the soil has been widely accepted to maintain soil fertility and to increase crop productivity. Residues of crops also enhance $\mathrm{N}_{2} \mathrm{O}$ and $\mathrm{CO}_{2}$ emissions (Baggs et al. 2000; Liu et al. 2014). Crop residues may affect $\mathrm{N}_{2} \mathrm{O}$ and $\mathrm{CO}_{2}$ emissions from soils in different ways, such as (1) supply of easily available organic carbon (OC), (2) supply of mineral N, (3) stimulation of microbial activities (Wu et al. 2015) and (4) increase in the oxygen consumption in the soil locally, creating optimal conditions for $\mathrm{N}_{2} \mathrm{O}$ production via denitrification (Lin et al. 2013). Soil incorporation of crop residues with easily mineralizable organic $\mathrm{C}$ and $\mathrm{N}$ may result in increased $\mathrm{N}_{2} \mathrm{O}$ and $\mathrm{CO}_{2}$ emissions into atmosphere (Velthof et al. 2002; Lou et al. 2007). However, the content of easily mineralizable organic matter differs significantly between crop residues (Henriksen and Breland 1999).

The magnitudes of soil $\mathrm{N}_{2} \mathrm{O}$ and $\mathrm{CO}_{2}$ emissions vary with the easily mineralizable organic contents, chemical composition and quality of the organic residues incorporated (Millar and Baggs 2004; Liu et al. 2014). Several studies have revealed the emissions of $\mathrm{N}_{2} \mathrm{O}$ and $\mathrm{CO}_{2}$ following different species of organic residue incorporation into soil (Jianwen et al. 2004; Millar et al. 2004; Novoa and Tejeda 2006: Liu et al. 2014). However, $\mathrm{N}_{2} \mathrm{O}$ and $\mathrm{CO}_{2}$ emissions from above- and below-ground biomass of crops, especially legume crops, are still unclear. Some researchers reported that the decomposition of root residues was slower than the shoot residues of the same plant due to the differences in their chemical compositions such as cellulose, organic carbon, nitrogen and lignin contents (Puget and Drinkwater 2001; Lu et al. 2003). Millar and Baggs (2004) stated that $\mathrm{N}_{2} \mathrm{O}$ emissions from soils were mostly related to the quality of the plant litter. Mineralization of plant 
residues and the emission of $\mathrm{N}_{2} \mathrm{O}$ were found to be dependent upon the composition of the residues (Németh et al. 1996; Shelp et al. 2000; Laville et al. 2011).

Legume crops are supposed to stimulate $\mathrm{N}_{2} \mathrm{O}$ emissions by increasing $\mathrm{N}$ inputs into soils. Therefore, legume crops can attribute largely $\mathrm{N}$ release into atmosphere upon decomposition of crop residues, including nodules of roots. Upon decomposition, root nodules of legume crops can release substantial amounts of ammonium and nitrate concentrations in the soil (Rochette et al. 2004). Nitrate $\left(\mathrm{NO}_{3}^{-}-\mathrm{N}\right)$ and ammonium $\left(\mathrm{NH}_{4}^{+}-\mathrm{N}\right)$ can contribute $\mathrm{N}_{2} \mathrm{O}$ emissions during microbial nitrification and denitrification in soil (Mahvi et al. 2005). Therefore, legume root nodules should not be neglected as concern to emissions of greenhouse gases. Similarly, Al-Kaisi and Yin (2005) demonstrated that incorporation of crop residues in cornsoybean field markedly increased $\mathrm{CO}_{2}$ emissions. Soil organic $\mathrm{C}$ was increased in crop residues incorporated soil which enhanced $\mathrm{CO}_{2}$ release into atmosphere.

To the best of our knowledge, there is less information about soil $\mathrm{N}_{2} \mathrm{O}$ and $\mathrm{CO}_{2}$ emissions from above- and belowground biomass of legume crops. We hypothesized that the differences in $\mathrm{N}_{2} \mathrm{O}$ and $\mathrm{CO}_{2}$ emissions from crop residues are based on contents of mineralizable $\mathrm{N}$ and $\mathrm{C}$ and depend on the type of crop residue. Therefore, we planned a laboratory study to evaluate the differences in $\mathrm{N}_{2} \mathrm{O}$ and $\mathrm{CO}_{2}$ emissions from root nodules residue and straw of green bean (Phaseolus vulgaris L.).

\section{Materials and Methods}

\section{Soil sampling and analysis}

The soil was sampled at $0-20 \mathrm{~cm}$ depth from a cultivated paddy field in Qianjiang city of Hubei province, China $\left(30^{\circ} 25^{\prime} 17.6^{\prime \prime} \mathrm{N}, 112^{\circ} 50^{\prime} 81.7^{\prime \prime} \mathrm{E} ; 50 \mathrm{~m}\right.$ above sea level). After manual removal of visible plant residues and roots, air-dried soil samples were ground to pass through a 2-mm sieve for incubation and soil analysis. Soil is classified as loam alluvial soil. The main characteristics of these soils are shown in Table 1.

The particle size distribution was analyzed using the pipette method. Soil $\mathrm{pH}$ was measured using a combined electrode and $\mathrm{pH}$ meter (PB-10; Sartorius AG, Germany) in a 1:2.5 (soil: distilled water) mixture (de Santiago-Martín et al. 2013; Shaaban et al. 2013a). Soil bulk density was determined by retrieving cores of known volume which were subsequently oven-dried at $105{ }^{\circ} \mathrm{C}$ for $24 \mathrm{~h}$ (Shaaban et al. 2013b). Soil $\mathrm{NH}_{4}^{+}-\mathrm{N}$ and $\mathrm{NO}_{3}^{-}-\mathrm{N}$ were extracted from 1:5 (soil: $1 \mathrm{M} \mathrm{KCl}$ ) mixture and analyzed using an auto sampler and analyzer (AutoAnalyzer-3, Seal, Germany) (Shaaban et al. 2014a). Total organic $\mathrm{C}$ and $\mathrm{N}$ in the residues were analyzed using dichromate oxidation method and Kjeldahl procedure, respectively (Page 1982). Dissolved organic carbon (DOC) was extracted by deionized water, and the supernatant was filtered through a filter membrane of $0.45 \mu \mathrm{m}$ (Shaaban et al. 2014b). The DOC was analyzed using a C/N Elemental Analyzer (Vario-Max $\mathrm{CN}$, Germany). Microbial biomass carbon (MBC) was estimated using the chloroform fumigation extraction method (Lin et al. 2013). Both the non-fumigated and fumigated soil extracts were filtered through a filter membrane of $0.45 \mu \mathrm{m}\left(\right.$ PES $^{\circledR}$, USA). The contents of MBC were analyzed using $\mathrm{C} / \mathrm{N}$ Elemental Analyzer (Vario-Max $\mathrm{CN}$, Germany) and estimated using the following factor:

$\mathrm{MBC}=2.22 E_{c}$

where $E_{c}$ is the difference between organic C extracted of fumigated and non-fumigated soils.

\section{Experimental setup}

Root nodule residue and straw of green bean (Phaseolus vulgaris L.) were obtained from a cultivated field after the harvest of green bean crop. The straw and root residues were oven-dried and ground to pass through a 1-mm sieve. The treatments were arranged as follows: control (CK),

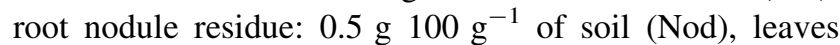
and shoot straw: $0.5-100 \mathrm{~g}^{-1}$ soil (LS). Each treatment comprised three replicates. One-liter glass bottles $($ depth $\times$ height $=10 \times 14 \mathrm{~cm})$ were used for incubation. The entire experiment was carried out under aerobic conditions at $25{ }^{\circ} \mathrm{C}$ for 53 days.

One set of glass bottles was used to measure $\mathrm{N}_{2} \mathrm{O}$ and $\mathrm{CO}_{2}$ emissions with $100 \mathrm{~g}$ soil in each bottle, while the other set was used for soil analysis with $400 \mathrm{~g}$ soil in each bottle. The soil was incubated in the bottles for 1 week (pre-incubation) to initiate the microbial activity prior to addition of organic residues. After 1 week of pre-incubation, distilled water was added to obtain $55 \%$ water-filled pore space (WFPS) in each glass bottle. After that, the organic amendments were added and mixed thoroughly with soil. Moisture content was maintained at $55 \%$ WFPS by weighing the glass bottles twice a week and adding distilled water if needed.

\section{Gas sampling and analysis}

The lids of glass bottles were fitted with a gas-tight rubber septum and a three-way stopcock to allow sampling the trace gases. Glass bottles were stored in an electric incubator at controlled temperature of $25^{\circ} \mathrm{C}$ in the dark under aerobic conditions. A thin polythene sheet was placed over the tops of the bottles. Approximately, 40 pinholes per bottle were pierced to allow gaseous exchange but prevent 
Table 1 Characteristics of soil and organic residues used in the experiment

\begin{tabular}{lrrr}
\hline Properties & \multicolumn{1}{c}{ Soil } & Leave and shoot & Root nodules residue \\
\hline $\mathrm{pH}$ & 7.93 & & \\
Total carbon (\%) & 1.91 & 40.10 & 32.35 \\
Total nitrogen (\%) & 0.16 & 2.28 & 3.00 \\
$\mathrm{C}: \mathrm{N}$ ratio & 11.94 & 17.59 & 10.78 \\
Total organic carbon (\%) & 1.84 & & \\
Dissolved organic carbon $\left(\mathrm{mg} \mathrm{kg}^{-1}\right)$ & 126.77 & & \\
$\mathrm{NH}_{4}^{+}-\mathrm{N}\left(\mathrm{mg} \mathrm{kg}^{-1}\right)$ & 4.38 & & \\
$\mathrm{NO}_{3}^{-}-\mathrm{N}\left(\mathrm{mg} \mathrm{kg}^{-1}\right)$ & 3.06 & & \\
Bulk density $\left(\mathrm{g} \mathrm{cm}^{-3}\right)$ & 1.20 & & \\
Clay $(\%)$ & 12.10 & & \\
Silt $(\%)$ & 47.66 & & \\
Sand $(\%)$ & 40.22 & & \\
\hline
\end{tabular}

moisture loss. Polythene sheets were removed before sampling, and bottles were exposed to open air for $20 \mathrm{~min}$ to ensure that bottles were filled with ambient air. The bottles were closed for $2 \mathrm{~h}$, and two gas samples were taken from headspace with a 30-ml plastic syringe immediately after closure $\left(T_{0}\right)$ and after $2 \mathrm{~h}\left(T_{1}\right)$. The $T_{0}$ sample was subtracted from $T_{1}$ to get actual flux of trace gases. Over the incubation period, gas samples were taken from head space of glass bottles on day 1, 2, 3, 4, 5, 6, 7, 8, 11, $18,25,32,39,46$ and 53.

$\mathrm{N}_{2} \mathrm{O}$ and $\mathrm{CO}_{2}$ concentrations were simultaneously detected using a gas chromatograph (Agilent-7890A, USA). Concentrations of $\mathrm{N}_{2} \mathrm{O}$ and $\mathrm{CO}_{2}$ were analyzed by an electron capture detector (ECD) and a flame ionization detector (FID), respectively. The temperature of column was maintained at $40{ }^{\circ} \mathrm{C}$, while ECD was set at $300^{\circ} \mathrm{C}$. The oven and FID were operated at 50 and $300{ }^{\circ} \mathrm{C}$, respectively. $\mathrm{N}_{2} \mathrm{O}$ and $\mathrm{CO}_{2}$ concentrations were calculated by comparing the peak area with those of standard reference gasses (Beijing special gas factory). The fluxes were calculated as $\mu \mathrm{g} \mathrm{N}_{2} \mathrm{O}-\mathrm{N} \mathrm{kg}^{-1}$ and $\mathrm{mg} \mathrm{CO}_{2}-\mathrm{C} \mathrm{kg}^{-1}$ by using the ideal gas law and linear regression model at a temperature of $25^{\circ} \mathrm{C}$ (of incubation) and an average air pressure during the specified period. Soil samples were taken concurrently with gas samples to analyze soil $\mathrm{NH}_{4}^{+}-$ $\mathrm{N}, \mathrm{NO}_{3}^{-}-\mathrm{N}, \mathrm{DOC}$ and $\mathrm{MBC}$.

\section{Statistical analyses}

All the statistical analyses were performed using the SPSS statistics package (SPSS 16.0). Statistically significant differences were identified by analysis of variance (ANOVA). Tukey's post hoc tests were utilized to identify the significant differences $p \leq 0.05$ and $p \leq 0.01$. Pearson's correlations between the trace gases and soil variables were calculated using the same statistical package.

\section{Results and Discussion}

\section{Effect of organic residues on soil $\mathrm{N}_{2} \mathrm{O}$ emissions}

Incorporation of organic residues significantly $(p \leq 0.05)$ influenced and increased $\mathrm{N}_{2} \mathrm{O}$ emissions. However, Nod treatments yielded greater $\mathrm{N}_{2} \mathrm{O}$ emissions as compared to LS treatment (Table 2). $\mathrm{N}_{2} \mathrm{O}$ emissions increased rapidly and peaked at 9.23 and $3.94 \mu \mathrm{g} \mathrm{N} 2 \mathrm{O}-\mathrm{N} \mathrm{kg}^{-1} \mathrm{~h}^{-1}$ on day 5 in Nod and LS treatments, respectively (Fig. 1). The emissions of $\mathrm{N}_{2} \mathrm{O}$ then decreased gradually until the end of the study. However, $\mathrm{N}_{2} \mathrm{O}$ emission in control (no organic residue) was constantly low throughout the study period. The cumulative $\mathrm{N}_{2} \mathrm{O}$ fluxes were 13-fold and fourfold in the Nod and LS treatments as compared to the control, respectively (Table 2 ).

Research has demonstrated that application of organic amendments increases soil organic $\mathrm{C}$ which further accelerates microbial processes such as nitrification and denitrification responsible for $\mathrm{N}_{2} \mathrm{O}$ production (Baggs et al. 2000). Incorporation of various organic residues to yellowbrown soil in central China also demonstrated the enhanced $\mathrm{N}_{2} \mathrm{O}$ emissions but varied among crop residues (Lin et al. 2013). The differences in magnitudes of $\mathrm{N}_{2} \mathrm{O}$ emissions varied depending on the composition, type and $\mathrm{C} / \mathrm{N}$ ratios of the crop residues. Flessa and Beese (1995) indicated that the effect of crop residue application on $\mathrm{N}_{2} \mathrm{O}$ emission was dependent on the $\mathrm{C}$ and $\mathrm{N}$ contents of different crop residues. The $\mathrm{C}$ and $\mathrm{N}$ contents of crop residue play an important role in $\mathrm{N}_{2} \mathrm{O}$ emissions (Frimpong and Baggs 2010). The optimum $\mathrm{C} / \mathrm{N}$ ratio for soil microbial activities is thought to range from 25 to 30 . Nitrogen release is facile from mineralization of organic compounds with $\mathrm{C} / \mathrm{N}$ ratios lower than 20, neither release nor immobilization prevails for $\mathrm{C} / \mathrm{N}$ ratios between 25 and 30 , and microbes immobilize inorganic $\mathrm{N}$ when the $\mathrm{C} / \mathrm{N}$ ratio is higher than 30 (Flessa and Beese 1995). Therefore, organic residues with 
Table $2 \mathrm{~N}_{2} \mathrm{O}$ and $\mathrm{CO}_{2}$ emissions from above- and below-ground biomass of green bean

\begin{tabular}{|c|c|c|c|c|c|c|}
\hline \multirow[t]{2}{*}{ Treatments } & \multicolumn{3}{|l|}{$\mathrm{N}_{2} \mathrm{O}-\mathrm{N}$} & \multicolumn{3}{|l|}{$\mathrm{CO}_{2}-\mathrm{C}$} \\
\hline & $\begin{array}{l}\text { Range } \\
\left(\mu \mathrm{kg}^{-1} \mathrm{~h}^{-1}\right)\end{array}$ & $\begin{array}{l}\text { Mean } \\
\left(\mu \mathrm{gg}^{-1} \mathrm{~h}^{-1}\right)\end{array}$ & $\begin{array}{l}\text { Cumulative } \\
\left(\mu \mathrm{kg}^{-1}\right)\end{array}$ & $\begin{array}{l}\text { Range } \\
\left(\mathrm{mg} \mathrm{kg}^{-1} \mathrm{~h}^{-1}\right)\end{array}$ & $\begin{array}{l}\text { Mean } \\
\left(\mathrm{mg} \mathrm{kg}^{-1} \mathrm{~h}^{-1}\right)\end{array}$ & $\begin{array}{l}\text { Cumulative } \\
\left(\mathrm{mg} \mathrm{kg}^{-1}\right)\end{array}$ \\
\hline CK & $0.02-0.65$ & $0.32 \mathrm{c}$ & $198.51 \mathrm{c}$ & $0.03-1.69$ & $0.92 \mathrm{~b}$ & $724.72 \mathrm{~b}$ \\
\hline Nod & $0.18-9.23$ & $3.61 \mathrm{a}$ & $2598.10 \mathrm{a}$ & $0.12-2.19$ & $1.07 \mathrm{~b}$ & $836.66 \mathrm{~b}$ \\
\hline LS & $0.00-3.94$ & $1.46 \mathrm{~b}$ & $808.61 \mathrm{~b}$ & $0.12-6.40$ & $2.45 \mathrm{a}$ & $1560.43 \mathrm{a}$ \\
\hline
\end{tabular}

Data are means of three replicate samples. Different letters within columns indicate significant differences at $p \leq 0.05$ by Tukey's test $C K$ control, Nod residue of root nodules, $L S$ leave and shoot straw

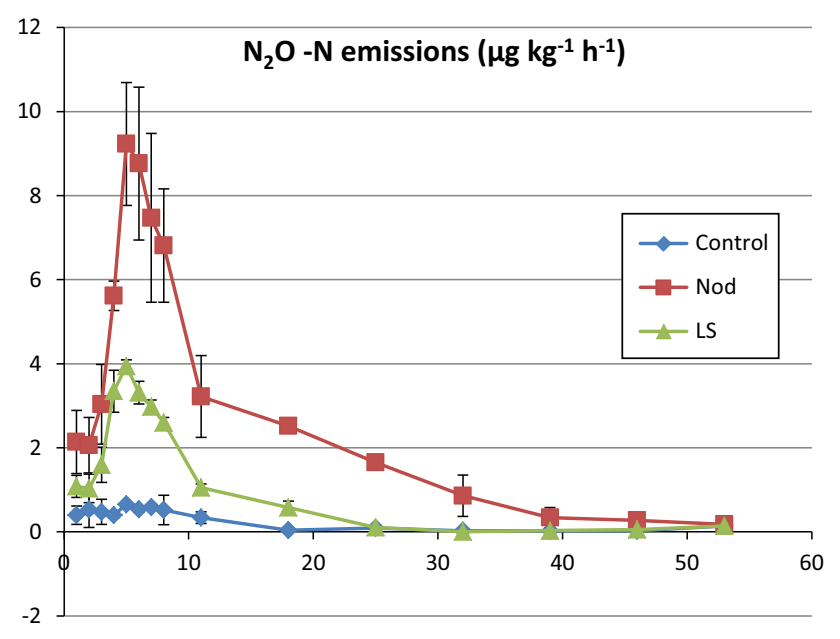

Fig. $1 \mathrm{~N}_{2} \mathrm{O}$ emission from control, Nod (root nodules) and LS (leave and shoot straw), vertical bars represent standard deviations $(n=3)$

lower $\mathrm{C} / \mathrm{N}$ ratios are generally decomposed faster than the residues with higher $\mathrm{C} / \mathrm{N}$ ratios. In the present study, the root nodule residue was characterized with a lower $\mathrm{C} / \mathrm{N}$ ratio of 10.78 as compared to $\mathrm{LS}$ which had a $\mathrm{C} / \mathrm{N}$ ratio of 17.59 (Table 1). The root residues (in Nod treatment) therefore more rapidly decomposed and yielded higher $\mathrm{N}_{2} \mathrm{O}$ emissions as compared to the LS treatment.

The increased $\mathrm{N}_{2} \mathrm{O}$ emissions in Nod treatment could be explained by the $\mathrm{N}$ contents in soil following incorporation of organic residues. The mineralization of root nodules generated higher mineral $\mathrm{N}$ contents in soil as compared to the LS treatment (Fig. 3, 4). Ammonium $\left(\mathrm{NH}_{4}^{+}-\mathrm{N}\right)$ concentration increased rapidly and reached at 61.04 and $43.95 \mathrm{mg} \mathrm{kg}^{-1}$ on day 2 in Nod and LS treatments, respectively. Afterward, $\mathrm{NH}_{4}^{+}-\mathrm{N}$ concentration gradually decreased and reached to the values almost same as in control on day 18 of incubation (Fig. 3). Nitrate $\left(\mathrm{NO}_{3}^{-}-\mathrm{N}\right)$ concentration continuously increased during the entire incubation and reached at 52.10 and $49.52 \mathrm{mg} \mathrm{kg}^{-1}$ on day 53 in Nod and LS treatments, respectively (Fig. 4). Higher mineral N contents in Nod treatment yielded higher soil $\mathrm{N}_{2} \mathrm{O}$ emissions. These results are in accord with the earlier studies where decomposition of plant residues with low $\mathrm{C} / \mathrm{N}$ ratio released higher soil $\mathrm{N}_{2} \mathrm{O}$ emissions (Huang et al. 2004; Millar et al. 2004). Faster decomposition of root nodule as compared to LS treatment led to the increased $\mathrm{NH}_{4}^{+}-\mathrm{N}$ and $\mathrm{NO}_{3}^{-}-\mathrm{N}$ concentrations which are $\mathrm{N}_{2} \mathrm{O}$ precursors in the soil. Therefore, it appeared from the results of our study that below-ground residues with low $\mathrm{C} / \mathrm{N}$ ratio contributed to higher $\mathrm{N}_{2} \mathrm{O}$ emissions in the Nod treatment when compared to the LS treatment. Moreover, $\mathrm{N}_{2} \mathrm{O}$ emissions and soil $\mathrm{N}$ contents were higher at early stage and lower at later stage of incubation. This concurrent occurrence of higher $\mathrm{N}_{2} \mathrm{O}$ emissions and soil $\mathrm{N}$ contents implies that the $\mathrm{N}$ contents were also critical in controlling soil $\mathrm{N}_{2} \mathrm{O}$ emissions.

Another explanation of higher $\mathrm{N}_{2} \mathrm{O}$ emissions in Nod treatment is the increased oxygen $\left(\mathrm{O}_{2}\right)$ consumption and denitrifiers activity (Millar and Baggs 2004). We conjecture that the decomposition of organic residues consumed oxygen, which created feasible conditions for denitrification stimulating $\mathrm{N}_{2} \mathrm{O}$ production. The findings of Lin et al. (2013) also support our results as they reported that enhanced soil $\mathrm{C}$ availability in plant residue incorporated soil accelerated the activities of microbes which during respiration decreased oxygen in the soil, resultantly higher $\mathrm{N}_{2} \mathrm{O}$ emissions. Microbial activities in soil can demonstrate trend of $\mathrm{N}_{2} \mathrm{O}$ release from soil to the atmosphere (Dambreville et al. 2006). Microbial biomass C (MBC) is one of the most active components of the soil organic $\mathrm{C}$ that indicates the activities and growth of microbes and regulates a variety of biochemical processes in the soil. Paul (2006) found an increased $\mathrm{N}_{2} \mathrm{O}$ emission relative to increased $\mathrm{MBC}$ contents. In the present study, positive relationships $(r=0.43, p \leq 0.01)$ were observed between $\mathrm{N}_{2} \mathrm{O}$ emissions and soil MBC contents (Table 3), indicating that enhanced microbial activity following incorporation of organic residues yielded high $\mathrm{N}_{2} \mathrm{O}$ emissions. Therefore, higher $\mathrm{N}_{2} \mathrm{O}$ emission at early stage of incubation was associated with higher contents of MBC, which was later on decreased with the decrease of MBC. This is in agreement with earlier observations where higher $\mathrm{N}_{2} \mathrm{O}$ emissions were associated with higher MBC contents in soils (Lou et al. 2007). 
Table 3 Pearson correlations among variables

\begin{tabular}{|c|c|c|c|c|c|c|}
\hline Variables & $\mathrm{N}_{2} \mathrm{O}$ & $\mathrm{NH}_{4}^{+}-\mathrm{N}$ & $\mathrm{NH}_{3}^{-}-\mathrm{N}$ & $\mathrm{CO}_{2}$ & DOC & MBC \\
\hline $\mathrm{N}_{2} \mathrm{O}$ & - & & & & & \\
\hline $\mathrm{NH}_{4}^{+}-\mathrm{N}$ & $0.69 *$ & - & & & & \\
\hline $\mathrm{NO}_{3}^{-} n-\mathrm{N}$ & $-0.25^{*}$ & $-0.66^{*}$ & - & & & \\
\hline $\mathrm{CO}_{2}$ & $0.28^{*}$ & $0.45^{*}$ & $-0.62 *$ & - & & \\
\hline DOC & $0.40 *$ & $0.68 *$ & $-0.74 *$ & $0.82 *$ & - & \\
\hline MBC & $0.43^{*}$ & $0.68^{*}$ & $0.64 *$ & $0.79 *$ & $0.89^{*}$ & - \\
\hline
\end{tabular}

* Correlation is significant at $p \leq 0.01(n=135)$

The amount of dissolved organic C (DOC) can also affect $\mathrm{N}_{2} \mathrm{O}$ emissions from soils (Lin et al. 2013). The contents of DOC reflect easily available $\mathrm{C}$ to microbes as a substrate for growth and metabolism (Jensen et al. 1997). The increased availability of DOC stimulated $\mathrm{N}_{2} \mathrm{O}$ emissions (Kaiser et al. 1998). Martin-Olmedo and Rees (1999) revealed that poultry manure increased DOC in soil which further increased $\mathrm{N}_{2} \mathrm{O}$ emissions. In our study, DOC contents positively correlated with $\mathrm{N}_{2} \mathrm{O}$ emissions. These results are supported by the findings of Sanchez-Martin et al. (2010) as they observed a positive correlation between soil DOC and $\mathrm{N}_{2} \mathrm{O}$ emissions. Furthermore, the majority of microbial denitrification relies on heterotrophic bacteria which require an organic carbon source (Wang and Wang 2012). The positive relationship between $\mathrm{N}_{2} \mathrm{O}$ emissions and DOC implies that enhanced activity of denitrifying bacteria contributed to higher $\mathrm{N}_{2} \mathrm{O}$ emissions after decomposition of organic residue.

\section{Soil $\mathrm{CO}_{2}$ emissions}

Incorporation of organic residues to soil significantly $(p \leq 0.05)$ influenced and enhanced $\mathrm{CO}_{2}$ emissions (Table 2). The magnitudes of $\mathrm{CO}_{2}$ emissions were greater in the LS treatment as compared to the Nod treatment. $\mathrm{CO}_{2}$ emissions increased and peaked at 6.40 and $2.19 \mathrm{mg} \mathrm{CO}_{2}-$ $\mathrm{C} \mathrm{kg}^{-1} \mathrm{~h}^{-1}$ on day 3 in LS and Nod treatments, respectively (Fig. 2). The emissions of $\mathrm{CO}_{2}$ then gradually decreased until the end of the study. Compared to the control, the cumulative $\mathrm{CO}_{2}$ fluxes were increased by up to 2.15-fold and 1.15-fold in the LS and Nod treatments, respectively (Table 2). Similar results were observed in an earlier study where higher $\mathrm{CO}_{2}$ emissions were found from the soils amended with the residues composed of high $\mathrm{C}$ contents (Millar and Baggs 2004). Higher C contents in LS treatment attributed to higher emissions of $\mathrm{CO}_{2}$ than that of Nod. The results show that $\mathrm{CO}_{2}$ emissions were highly dependent on the $\mathrm{C}$ contents of amended crop residues.

Incorporation of organic residues significantly $(p \leq 0.05)$ increased DOC in the present study and higher DOC contents were found in the LS treatment as compared

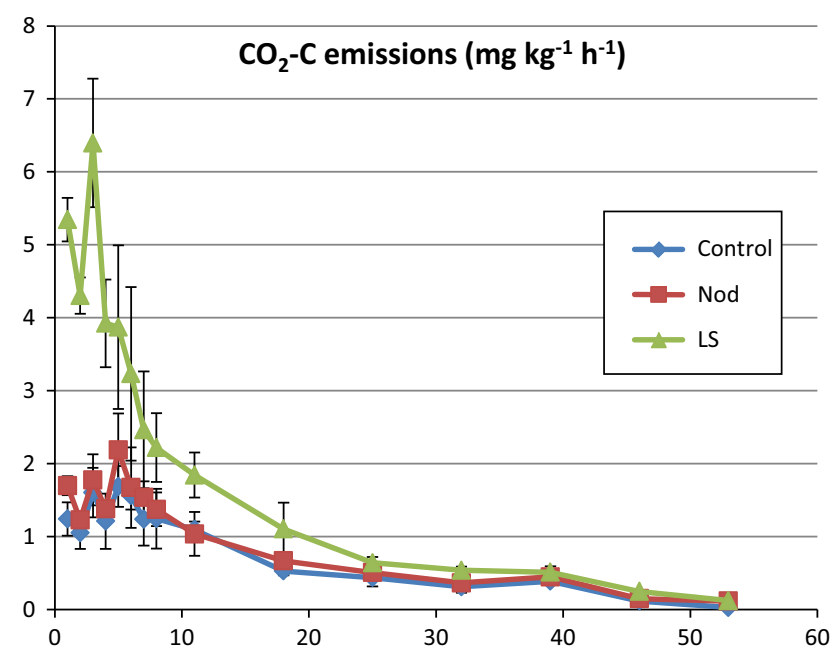

Fig. $2 \mathrm{CO}_{2}$ emission from control, Nod (root nodules) and LS (leave and shoot straw), vertical bars represent standard deviations $(n=3)$

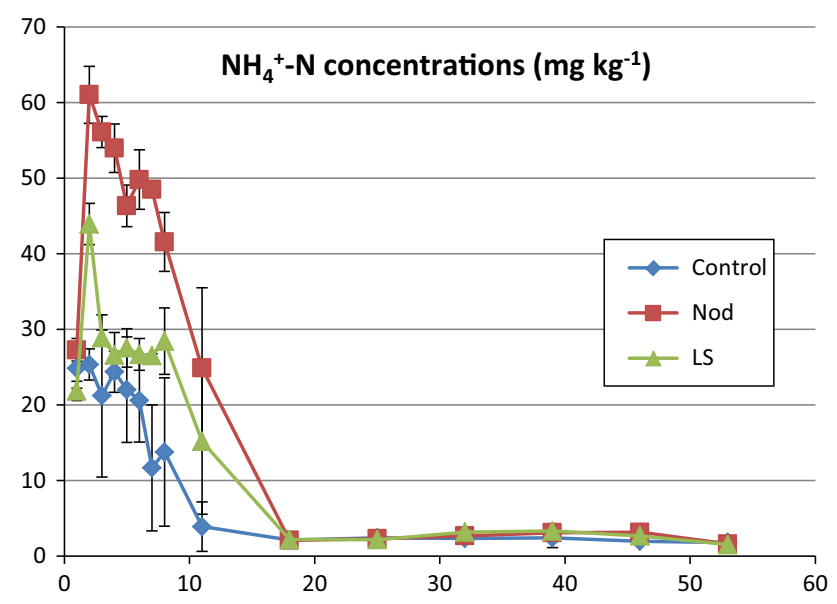

Fig. 3 Ammonium concentrations in control, Nod (root nodules) and LS (leave and shoot straw), vertical bars represent standard deviations $(n=3)$

to the Nod treatment (Fig. 5). Upon incorporation of organic residues, DOC contents were peaked at 253.53 and $171.15 \mathrm{mg} \mathrm{kg}^{-1}$ on day 2 in LS and Nod treatments, respectively. After that, DOC gradually decreased until the end of the incubation period. Pearson's correlation analysis also showed that soil $\mathrm{CO}_{2}$ emissions were strongly correlated with DOC ( $r=0.82, p \leq 0.01$, Table 3$)$, indicating that increased $\mathrm{C}$ supply after residue incorporation promoted soil respiration. Changes in DOC contents may potentially cause fluctuations in the magnitude of $\mathrm{CO}_{2}$ emissions (Davidson et al. 2000). As a specific fraction of organic C, dissolved organic carbon (DOC) represents an easily degradable and available substrate to microorganisms (Boyer and Groffman 1996; Huang et al. 2014). Soil respiration has been revealed to be reliant on $\mathrm{C}$ supply 


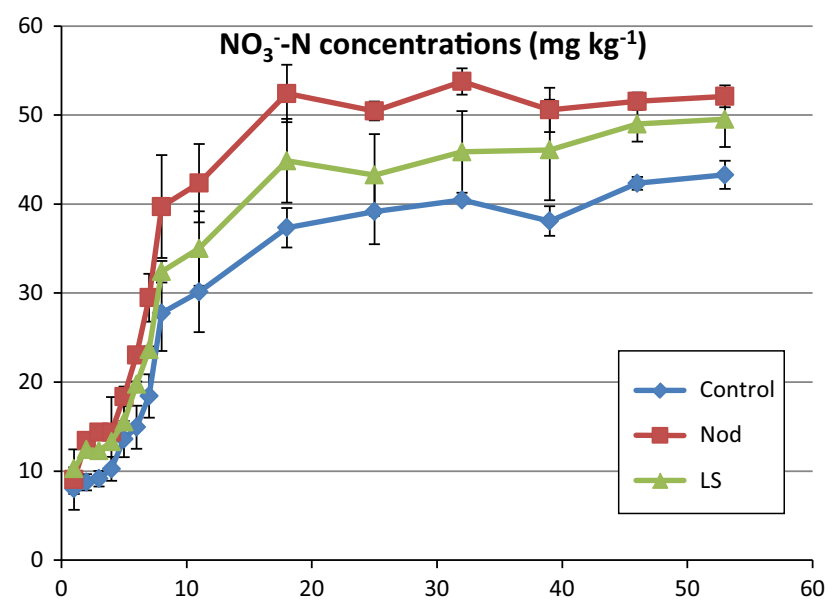

Fig. 4 Nitrate concentrations in control, Nod (root nodules) and LS (leave and shoot straw), vertical bars represent standard deviations $(n=3)$

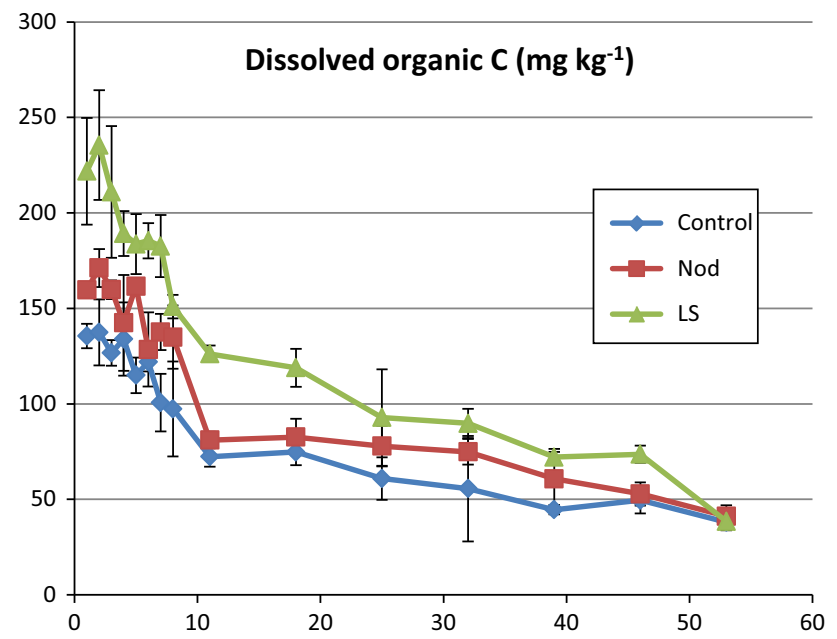

Fig. 5 Dissolved organic carbon in control, Nod (root nodules) and LS (leave and shoot straw), vertical bars represent standard deviations $(n=3)$

(Silva et al. 2009; Sevilla-Perea et al. 2015). In an earlier study, rice straw addition enhanced availability of organic $\mathrm{C}$ and microbial activities which accounted for the increase in soil $\mathrm{CO}_{2}$ emissions (Bhattacharyya et al. 2012). Our results showed that $\mathrm{CO}_{2}$ emissions were higher in LS treatment that had higher $\mathrm{C}$ contents of $40.10 \%$ than that of Nod treatment with $32.35 \% \mathrm{C}$ contents. Therefore, the larger magnitudes of $\mathrm{CO}_{2}$ were released from LS treatment as compared to Nod treatment.

$\mathrm{CO}_{2}$ emission was high at the beginning of the incubation and maximum on day 2 of the commencement of experiment. DOC contents were also high at the early stage and lower at later stage of incubation (Fig. 5). The increase in carbon supply stimulated microbial activities in LS treatment and thereby higher $\mathrm{CO}_{2}$ emissions at the early

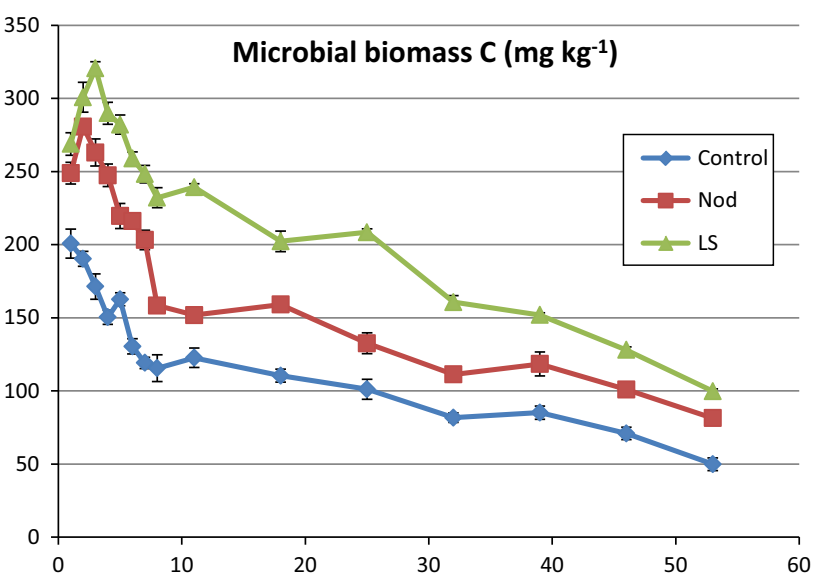

Fig. 6 Microbial biomass carbon in control, Nod (root nodules) and LS (leave and shoot straw), vertical bars represent standard deviations $(n=3)$

stage of incubation. Similar results were observed by Duong et al. (2009) as they reported that the maximum $\mathrm{CO}_{2}$ evolved immediately after 1 day of the onset of incubation with wheat straw at an application dose of $2 \%$ in a sandy loam soil. The authors explained that the mechanism of the high respiration rates at the beginning of experiment was due to easily available organic compounds following wheat straw addition. In another study, the incorporation of rice straw increased $\mathrm{CO}_{2}$ emissions within 10 days and then gradually decreased (Lou et al. 2007). Results of our study are in agreement with the above-discussed studies as $\mathrm{CO}_{2}$ emissions were higher at high levels of DOC contents (Figs. 2, 5).

Microbial activities are considerably influenced by incorporation of organic residues depending on the type of incorporated material (Lin et al. 2013). Microbial biomass carbon (MBC) was increased significantly $(p \leq 0.05)$ by the incorporation of organic residues. MBC was higher in LS treatment as compared to Nod treatment. MBC increased rapidly and reached at 320.51 and $280.65 \mathrm{mg} \mathrm{kg}^{-1}$ in LS and Nod treatments, respectively, on days 3 and 2 of the study period (Fig. 6). Afterward, MBC decreased steadily until the end of the study. Positive and significant correlation between $\mathrm{MBC}$ and $\mathrm{CO}_{2}$ emissions $(r=0.79, p \leq 0.01)$ also confirmed that microbial respiration increased by the available $\mathrm{C}$ from organic residues. Our results are in agreement with Lou et al. (2007) as they found that soil $\mathrm{CO}_{2}$ fluxes positively correlated with DOC and MBC after 55 days of the experiment commencement. Bhattacharyya et al. (2012) also found significant correlations between $\mathrm{CO}_{2}$ emissions, $\mathrm{DOC}$ and $\mathrm{MBC}$ after rice straw and green manure application in a paddy soil. Overall, it is worthwhile to mention from our results that leave and shoot straw of green bean could regulate more $\mathrm{CO}_{2}$ emissions as compared to root nodules. 


\section{Conclusion}

The current study demonstrated the effects of above-ground (LS treatment) and below-ground biomass (Nod treatment) of green bean on $\mathrm{N}_{2} \mathrm{O}$ and $\mathrm{CO}_{2}$ emissions. Mineralization of both LS and Nod residues differed depending on the $\mathrm{C} / \mathrm{N}$ ratio. Root nodule residue showed higher mineralization rate and mineral $\mathrm{N}$ contents because of low $\mathrm{C} / \mathrm{N}$ ratio and thereby enhanced soil $\mathrm{N}_{2} \mathrm{O}$ emissions. Nevertheless, leave and shoot straw yielded higher $\mathrm{CO}_{2}$ emissions as compared to the root nodule residue. The findings of this study suggest that below-ground biomass of legume crops is capable of producing high soil $\mathrm{N}_{2} \mathrm{O}$ emissions while high soil $\mathrm{CO}_{2}$ emissions are released from above-ground biomass. Such information from laboratory study can open a window of exploring further research regarding decomposition of different crop biomass under various conditions and their impact on greenhouse gas emissions. Further research is needed to investigate $\mathrm{N}_{2} \mathrm{O}$ and $\mathrm{CO}_{2}$ emissions from aboveand below-ground biomass of a variety of crops.

Acknowledgments This research work was financially supported by National Natural Science Foundation of China (41171212) and National Basic Research Program of China (2012CB417106). Authors are grateful to the anonymous reviewers for comments and suggestions to improve the manuscript.

\section{References}

Al-Kaisi MM, Yin X (2005) Tillage and crop residue effects on soil carbon and carbon dioxide emission in corn-soybean rotations. J Environ Qual 34:437-445

Baggs E, Rees R, Smith K, Vinten A (2000) Nitrous oxide emission from soils after incorporating crop residues. Soil Use Manage 16(2):82-87

Bhattacharyya P, Roy K, Neogi S, Adhya T, Rao K, Manna M (2012) Effects of rice straw and nitrogen fertilization on greenhouse gas emissions and carbon storage in tropical flooded soil planted with rice. Soil Tillage Res 124:119-130

Boyer J, Groffman P (1996) Bioavailability of water extractable organic carbon fractions in forest and agricultural soil profiles. Soil Biol Biochem 28(6):783-790

Dambreville C, Hallet S, Nguyen C, Morvan T, Germon JC, Philippot L (2006) Structure and activity of the denitrifying community in a maize-cropped field fertilized with composted pig manure or ammonium nitrate. FEMS Microb Ecol 56(1):119-131

Davidson EA, Trumbore SE, Amundson R (2000) Biogeochemistry: soil warming and organic carbon content. Nature 408(6814): 789-790

de Santiago-Martín A, Valverde-Asenjo I, Quintana J, GonzálezHuecas C, Lafuente A (2013) Soil properties affecting metal extractability patterns in periurban calcareous agricultural soils in the Mediterranean area. Int J Environ Res 7:831-840

Duong TTT, Baumann K, Marschner P (2009) Frequent addition of wheat straw residues to soil enhances carbon mineralization rate. Soil Biol Biochem 41(7):1475-1482

Flessa H, Beese F (1995) Effects of sugarbeet residues on soil redox potential and nitrous oxide emission. Soil Sci Soc Am J 59(4):1044-1051
Frimpong K, Baggs E (2010) Do combined applications of crop residues and inorganic fertilizer lower emission of $\mathrm{N}_{2} \mathrm{O}$ from soil? Soil Use Manage 26(4):412-424

Henriksen TM, Breland TA (1999) Evaluation of criteria for describing crop residue degradability in a model of carbon and nitrogen turnover in soil. Soil Biol Biochem 31(8):11351149

Huang Y, Zou J, Zheng X, Wang Y, Xu X (2004) Nitrous oxide emissions as influenced by amendment of plant residues with different C:N ratios. Soil Biol Biochem 36(6):973-981

Huang J, Richard H, Zheng S (2014) Effects of nitrogen fertilization on soil labile carbon fractions of freshwater marsh soil in Northeast China. Int J Enviro Sci Tech 11(7):2009-2014

Jensen LS, Mueller T, Magid J, Nielsen NE (1997) Temporal variation of $\mathrm{C}$ and $\mathrm{N}$ mineralization, microbial biomass and extractable organic pools in soil after oilseed rape straw incorporation in the field. Soil Biol Biochem 29(7):1043-1055

Jianwen Z, Yao H, Lianggang Z, Xunhua Z, Yuesi W (2004) Carbon dioxide, methane, and nitrous oxide emissions from a rice-wheat rotation as affected by crop residue incorporation and temperature. Adv Atmos Sci 21(5):691-698

Kaiser EA, Kohrs K, Kücke M, Schnug E, Heinemeyer O, Munch J (1998) Nitrous oxide release from arable soil: importance of $\mathrm{N}$-fertilization, crops and temporal variation. Soil Biol Biochem 30(12):1553-1563

Laville P, Lehuger S, Loubet B, Chaumartin F, Cellier P (2011) Effect of management, climate and soil conditions on $\mathrm{N}_{2} \mathrm{O}$ and $\mathrm{NO}$ emissions from an arable crop rotation using high temporal resolution measurements. Agr Forest Meteorol 151(2): 228-240

Lin S, Iqbal J, Hu R, Shaaban M, Cai J, Chen X (2013) Nitrous oxide emissions from yellow brown soil as affected by incorporation of crop residues with different carbon-to-nitrogen ratios: a case study in central China. Arch Environ Contam Toxicol 65:183-192

Liu S, Hu R, Zhao J, Brüggemann N, Bol R, Cai G, Lin S, Shaaban M (2014) Flooding effects on soil phenol oxidase activity and phenol release during rice straw decomposition. J Plant Nutr Soil Sc 177:541-547

Lou Y, Ren L, Li Z, Zhang T, Inubushi K (2007) Effect of rice residues on carbon dioxide and nitrous oxide emissions from a paddy soil of subtropical China. Water Air Soil Poll 178(1):157-168

Lu Y, Watanabe A, Kimura M (2003) Carbon dynamics of rhizodeposits, root-and shoot-residues in a rice soil. Soil Biol Biochem 35(9): 1223-1230

Mahvi A, Nouri J, Babaei A, Nabizadeh R (2005) Agricultural activities impact on groundwater nitrate pollution. Int $\mathrm{J}$ Environ Sci Tech 2(1):41-47

Martin-Olmedo P, Rees R (1999) Short-term N availability in response to dissolved-organic-carbon from poultry manure, alone or in combination with cellulose. Biol Fert Soils 29(4):386-393

Millar N, Baggs E (2004) Chemical composition, or quality, of agroforestry residues influences $\mathrm{N}_{2} \mathrm{O}$ emissions after their addition to soil. Soil Biol Biochem 36(6):935-943

Millar N, Ndufa J, Cadisch G, Baggs E (2004) Nitrous oxide emissions following incorporation of improved-fallow residues in the humid tropics. Glob Biogeochem Cycles 18 (1):GB1032

Németh T, Abd El-Galil A, Radimszky L, Baczó G, Van Cleemput O, Hofman G, Vermoesen A (1996) Effect of plant residues on ammonium and nitrate content of soils during incubation. Devlop Plant Soil Sci 68:109-114

Novoa RS, Tejeda HR (2006) Evaluation of the $\mathrm{N}_{2} \mathrm{O}$ emissions from $\mathrm{N}$ in plant residues as affected by environmental and management factors. Nutr Cycl Agroecosys 75:29-46 
Page AL (1982) Methods of soil analysis. Part 2. Chemical and microbiological properties. Am Soc Agron, Soil Sci Soc Am pp 1159

Paul EA (2006) Soil microbiology, ecology and biochemistry. Academic press, Elsevier Inc., Burlington, MA

Puget P, Drinkwater L (2001) Short-term dynamics of root- and shoot-derived carbon from a leguminous green manure. Soil Sci Soc Am J 65(3):771-779

Rochette P, Angers DA, Bélanger G, Chantigny MH, Prévost D, Lévesque $\mathrm{G}$ (2004) Emissions of $\mathrm{N}_{2} \mathrm{O}$ from Alfalfa and Soybean crops in Eastern Canada. Soil Sci Soc Am J 68(2):493-506

Sanchez-Martin L, Sanz-Cobena A, Meijide A, Quemada M, Vallejo A (2010) The importance of the fallow period for $\mathrm{N}_{2} \mathrm{O}$ and $\mathrm{CH}_{4}$ fluxes and nitrate leaching in a Mediterranean irrigated agroecosystem. Eur J Soil Sci 61(5):710-720

Sevilla-Perea A, Hernández-Soriano M, Mingorance M (2015) Carbon mineralization from sewage sludge-amended mine dump by response surface methodology. Int J Environ Science Tech 12:125-138

Shaaban M, Abid M, Abou-Shanab R (2013a) Amelioration of salt affected soils in rice paddy system by application of organic and inorganic amendments. Plant Soil Environ 59(5):227-233

Shaaban M, Abid M, Qi-An P (2013b) Short term influence of gypsum, farm manure and commercial humic acid on physical properties of salt affected soil in rice paddy system. J Chem Soc Pakistan 35(3):1034-1040
Shaaban M, Peng Q, Hu R, Lin S, Wu Y, Ullah B, Zhao J, Liu S, Li Y (2014a) Dissolved organic carbon and nitrogen mineralization strongly affect $\mathrm{CO}_{2}$ emissions following lime application to acidic soil. J Chem Soc Pakistan 36:875-879

Shaaban M, Peng Q, Lin S, Wu Y, Zhao J, Hu R (2014b) Nitrous oxide emission from two acidic soils as affected by dolomite application. Soil Res 52:841-848

Shelp ML, Beauchamp EG, Thurtell GW (2000) Nitrous oxide emissions from soil amended with glucose, alfalfa, or corn residues. Commun Soil Sci Plan 31:877-892

Silva A, Nogueira D, Ikematsu P, Silveira F, Bomback M, Alves S, Paula F, Camargo P (2009) Carbon stocks and isotopic composition of the organic matter in soils covered by native vegetation and pasture in Sorocaba, SP, Brazil. Int J Environ Res $3: 435-440$

Velthof GL, Kuikman PJ, Oenema O (2002) Nitrous oxide emission from soils amended with crop residues. Nutr Cycl Agroecosys 62(3):249-261

Wang X, Wang J (2012) Denitrification of nitrate-contaminated groundwater using biodegradable snack ware as carbon source under low-temperature condition. Int $\mathrm{J}$ Environ Sci Techn 9(1):113-118

Wu Y, Liu T, Peng Q, Shaaban M, Hu R (2015) Effect of straw returning in winter fallow in Chinese rice fields on greenhouse gas emissions: evidences from an incubation study. Soil Res 53(3):298-305 